\title{
Investigating Literacy Practices in a University EFL Context from Multiliteracies and Multimodal Perspective: A Case Study
}

Salim Nabhan*, Rahmad Hidayat

English Language Education Department, Faculty of Teacher Training and Education, Universitas PGRI Adi Buana Surabaya, Jl. Dukuh Menanggal XII Surabaya, Indonesia

Corresponding Author: Salim Nabhan, E-mail: salimnabhan@unipasby.ac.id

\section{ARTICLE INFO}

Article history

Received: August 26, 2018

Accepted: October 22, 2018

Published: December 28, 2018

Volume: 9 Issue: 6

Advance access: November 2018

Conflicts of interest: None

Funding: The research is financed by Ministry of Research, Technology, and Higher Education of the Republic of Indonesia.
Key words:
Literacy,
Multiliteracies,
Multimodality,
Writing,
Reading,
English Language Education,
Higher Education Level

\begin{abstract}
This study attempts to investigate the literacy practices of EFL teaching and learning in higher education level from multiliteracies and multimodal perspective. Mixed methods were used: questionaires to the students, interviews with both teachers and students, focus group discussion with students, observation, and documents. The study was focused on the English reading and writing classroom activities. The results of the study revealed that most participating students frequently utilized on screen text and digital devices instead of printed paper in their reading and writing activities. In addition, despite the fact that teachers still used print-based literacy, they supported the adoption of digital and multimodal literacy in their teaching. The findings also indicated that there was mostly misconception of English literacy skills limited to the only targeted skills of English language, and yet the nature of reading and writing practices has developed towards incorportion of printed based texts with multimodal texts. Nevertheless, some challenges occured in integrating multimodality into practices including curriculum design and different learners' qualification. Findings collected from the this study might have implications for the curriculum development within the framework of multiliteracies and multimodality in the contemporary teaching and learning English language particularly in response to the emergence of technology.
\end{abstract}

\section{INTRODUCTION}

Todays' industrial revolution 4.0 has exposed some complexities as well as opportunities in educational context. Accordingly, literacy, in recent years, has become one of the important issues to challenge that disruptive era. Traditionally, the ability of reading and writing is considered as being literate, but due to the advancement of technology in the $21^{\text {st }}$ century, the concepts of literacy have gained more complex meaning. Therefore, those competences are not sufficient to face today's complex society. Scribner \& Cole (1981) asserted that literacy is not just simply the ability to read and write particular texts, but it includes the competency of implementing the knowledge for spesific purposes and contexts.

In the English language literacy, reading and writing are considered as foundation to the language development. Paxton \& Frith (2014) suggested that reading and writing are crucial skills in the teching and learning process of any subjects and in designing the curricula. Also, the skills of reading and writing have a strong corelation in which reading skill can support the writing skill (Krashen, 1990).

Understanding the significance of the newly literacy skills and the urg to accomodate the growing presence of technological access owned by the students to their day to day interraction and communication, the concept of English literacy education should be subtantially revised based on the contemporary students' needs, and the practice of English language learning and teaching should be shifted to be more adaptable to the recent situation. Hence, this challenges teachers to improve their literacy concept and pedagogical strategies and contextualise their classroom activities to the real world (Navehebrahim, 2011).

In response to such issues, this article focuses on the literacy practices of EFL classroom particularly in reading and writing activities that are seen from the perspective of multiliteracies pedagogy and multimodal approach with reference to the following research questions: (1) What are the 
students' literacy practices towards the use of printed, digital, and multimodal texts when they engage in reading and writing courses? (2) What literacy strategies do the teachers use in reading and writing with multimodal texts in their EFL classrooms? Therefore, the overall aim of this article is to investigate the literacy practices of EFL classroom activities in higher education level from the perspective of multiliteracies and multimodal approaches. Therein, multiliteracies pedagogy and multimodal approaches would be the alternative to promote the students' English language literacy.

\section{THEORITICAL CONSTRACTS}

\section{Multiliteracies Pedagogy}

In the mid of 1990s, a group of literacy scholars gathered in New London and proposed a new approach to literacy theory and pedagogy called multiliteracies. The approach can be described as a metalanguage in response to the expansion of language diversity and multimodal forms of communication (The New London Group, 2011). Multilitercies pedagogy was developed to change the focus from print based literature and linguistics skills implemented in teaching language and literacy.

Furthermore, Navehebrahim (2011) discusses that multiliteracies approach is a combination of various forms of knowledge, including utilizing and producing digital audio visual media through emerging technology which assist effective learning activities. Burke \& Hardware (2016) explain that multiliteracies accomodated other forms of literacies that include oral, audio, spatial, information literacy, and visual literacy. This idea has generated the concept of New Literacy Study (NLS). This interdisciplinary approach has contributed to the efficacy of literacy education that allows students to learn the skills and the knowledge through different modes of communication.

\section{Multimodality and English Language Teaching}

Multimodal approach, as defined by Kress, et al., (2005, p. 2), is "one where attention is given to all culturally shapes resources that are available for making meaning." They can be in the form of image, gesture, layout, writing, and speech as talk. This is to say that the multimodality is identified by the use and combination of multiplicity of modes. The use of certain modes may be more dominant than the others, and they occur simultaneously. The distinction between the two concepts, multiliteracies and multimodality, according to Roswell \& Walsh (as cited in Burke \& Hardware, 2016), that multiliteracies pedagogy focuses on the use of multimodalities in communication and linguistics diversity, while multimodality deals how individuals generates meaning with different types of modes. Hence, multiliteraces is the pedagogy that is used by individuals to promote multimodality.

Some recent studies (Crowder, Choi, \& Yi, 2013; Drajati, Tan, Haryati, Rochsantiningsih, \& Zainnuri, 2018; Navehebrahim, 2011; Walsh, 2010; Ganapathy \& Seetharam, 2016) have indicated that multiliteracies and multimodality approach have been positively suggested as one perspective in teaching English language.

\section{METHODS}

\section{Study Design}

A case study involving quantitative and qualitative methods was undertaken for the purpose of giving a depth account of the literacy practices in the teaching and learning English language from the perspective of multiliteracies and multimodality. The study was focused on reading and writing in EFL classroom activities. In order to answer the research problems, five research methods were used. They were questionaires to the students, interviews with the teachers, focus group discussion with students, observation, and documents. The questionaires survey given to the students were used to identify the students' literacy practices towards the use of printed, digital, and multimodal texts in reading and writing activities. The methodological triangulation of teachers' interviews, observation, and documents was utilized to explore the teachers' literacy practices in their reading and writing activities.

Two types of data collection, quantitative and qualitative, were used. The quantitative data were from students' questionaires. There were thirty seven questionaires that were submitted; the researcher then coded and imputted them into the statistical analysis software packages SPSS for data analysis in the form of descriptive statistics in terms of frequency (precentage of the total number). The qualitative data were derived from teachers' interviews, students' focus group discussion, and documents. While the teachers' interview and documents were used to investigate the teachers' literacy practices in their reading and writing classroom activities, one focus group discussion was used to explore more detail information regarding the students' behaviour towards literacy practices. In addition, the observation was done in two different classrooms.

\section{Study Participants}

The subjects of the study were the university teachers who teach Reading and Writing courses and the students of English Language Education Department, Faculty of Teacher Training and Education, Universitas PGRI Adi Buana Surabaya, Indonesia. Two English Reading teachers and two English Writing teachers were involved in the study. While the researcher adopted a purposive sampling method in recruiting participants of the teachers, the students were taken randomly as participants from semester six. Additionally, one focus group discussion consisted of five students was conducted to gain more data.

\section{Data Collection}

The data took in the variety of forms: photograph, video, audio recording, fieldwork notes, documents, questionnaire, and interview as well as group discussion transcript. Questionnaire was adapted from Likert Scale consisting of several 
options of frequency, quality, and agreement. Field notes and video were used to reduce the observer bias and improve the reliability of qualitative data. Audio recording was also used when interview and focus group discussion were conducted. To avoid potential bias and distortion, the participants were invited as auditors to check the transcript and field notes.

\section{Ethical Considerations}

Before participating the study, the participants were provided with the explanation of the study. The written consent was also conducted before enrollment in the study. The recorded data were transcribed after the session and stored in a safe place.

\section{Data Analysis}

The quantitative data were analysed using descriptive analysis in terms of frequency (percentage) and SPSS software packages were utilized. The qualitative data analysis from interview and focus group discussion consisted of transcription and interpretation involving codes and categories development, theme identification, and concepts development (Descombe, 2007). In analysing the data, the researcher developed the codes, grouped them into categories, and then identified the theme based on the research questions. To confirm the validity of the final result, the researcher discussed the processes with the participants of the study.

\section{RESULT OF THE STUDY}

\section{Questionnaire Findings}

Questionnaire was used to identify the students' literacy practices towards the use of printed, digital, and multimodal texts in their reading and writing activities.

\section{Reading practices}

Use of materials in reading activities

Based on the research conducted to the students, the frequency of using the reading materials covering assigned printed books (modules), other printed materials (journals, book chapters, proceedings), and materials from the website (articles or newspapers in online journal) varied. Respectively $14.3 \%$ and $57.1 \%$ of the students read assigned printed books (modules) very frequently and frequently. While the rest $17.9 \%$ and $10.7 \%$ of students noted that they read assigned printed books (modules) occasionally and rarely. Most of the students $(50 \%)$ stated that they frequently read other printed materials and $21.4 \%$ of students occasionally read them. Meanwhile $14.3 \%$ of students very frequently read other printed materials and $14.3 \%$ of students rarely read them. Ragarding reading materials from website, most of the students $(60.5 \%)$ stated that they frequently read the materials from the website, $28.6 \%$ of students read the materials very frequently, and only $10.7 \%$ of students read them occasionally. The following Table 1 provides the summary of the use of materials in reading activities.

\section{Modes of reading}

Viewed from Table 2 regarding reading modes (printed dan digital texts) used by the students, in terms of printed texts, most of the students (42.5\%) frequently read printed books and $35.7 \%$ of students occasionally read them. Meanwhile, $10.7 \%$ of students stated that they read printed texts very frequently, $7.1 \%$ of students rarely read printed texts, and only $3.6 \%$ of students never read printed texts. In terms of digital texts, $57.1 \%$ of students answered that they read digital texts frequently and $32.1 \%$ of students read them very frequently. While the rest of students $(10.7 \%)$ occasionally read digital texts.

\section{Supporting media in reading/background knowledge building}

The questionnaire as seen in Table 3 also indicated the media utilized by students to increase their reading comprehension in the forms of pictures/images or videos. Seen from the use of images, the research showed that students frequently and very frequently used images reaching $53.6 \%$ and $17.9 \%$ respectively. Meanwhile, there were $10.7 \%$ of respondents using images occasionally and rarely, and only $3.6 \%$ of respondents never used them and very rarely. Related to the use of video, the study indicated that majority of students $(50 \%$ and $25 \%)$ used videos frequently and very frequently. Respectively $7.1 \%$ and $14.3 \%$ of students occasionally and rarely used videos. The rest $3.6 \%$ of students never used videos.

\section{Students' competency in using digital learning resources}

Concerning with the students' competency in employing digital learning resources, the questionnaire showed that majority of the students (53.6\%) were competent and $35.7 \%$ of students were satisfactory. The rest, there were $10.7 \%$ of students who were excellent in making use of digital learning resources. The following Table 4 is presented.

\section{Writing practices}

\section{Types of writing activities}

As shown in Table 5, the students' type of writing covered academic essays, classnotes, and blogs. The questionnaire revealed that respectively $42.9 \%$ and $28.6 \%$ of students wrote academic essays frequently and occasionally. Meanwhile, only $14.3 \%$ of students stated that they very frequently wrote academic essays, and $7.1 \%$ of students rarely and never wrote academic essays. Most of the students $(53.6 \%)$ frequently wrote classnotes and $21.4 \%$ of students occasionally wrote classnotes. The rest $21.4 \%$ of students and $3.6 \%$ of students very frequently and rarely wrote classnotes respectively. In the matter of writing blogs, $32.1 \%$ of respondents answered that they occasionally wrote blogs, $21.4 \%$ of them frequently wrote blogs, $10.7 \%$ of them very frequently wrote blogs. The rest $17.9 \%$ and $7.1 \%$ of students were rarely and very rarely 
Table 1. Use of materials in reading activities

\begin{tabular}{lcccccc}
\hline Use of materials & Very frequently \% & Frequently $\%$ & Occasionally $\%$ & Rarely $\%$ & Very rarely \% & Never \% \\
\hline Assigned printed books & 14.3 & 57.1 & 17.9 & 10.7 & 0 & 0 \\
Other printed materials & 14.3 & 50.0 & 21.4 & 14.3 & 0 & 0 \\
Materials from the websites & 28.6 & 60.7 & 10.7 & 0 & 0 & 0 \\
\hline
\end{tabular}

Table 2. Modes of reading

\begin{tabular}{lcccccc}
\hline Modes of reading & Very frequently $\%$ & Frequently $\%$ & Occasionally $\%$ & Rarely $\%$ & Very rarely $\%$ & Never $\%$ \\
\hline Printed texts & 10.7 & 42.9 & 35.7 & 7.1 & 0 & 3.6 \\
Digital texts & 32.1 & 57.1 & 10.7 & 0 & 0 & 0 \\
\hline
\end{tabular}

Table 3. Supporting media in reading activities

\begin{tabular}{lcccccc}
\hline Supporting media & Very frequently \% & Frequently $\%$ & Occasionally \% & Rarely \% & Very rarely \% & Never \% \\
\hline Pictures/images & 17.9 & 53.6 & 10.7 & 10.7 & 3.6 & 3.6 \\
Videos & 25.0 & 50.0 & 7.1 & 14.3 & 0 & 3.6 \\
\hline
\end{tabular}

Table 4. Students' competency in using digital resources

\begin{tabular}{lccccc}
\hline Students' competency & Excellent \% & Very good \% & Satisfactory \% & Fair \% & Poor \% \\
\hline Digital learning resources & 10.7 & 53.6 & 35.7 & 0 & 0 \\
\hline
\end{tabular}

\section{Media used in writing}

With regard to the media used by students in their writing activities as presented in Table 6, there were two tools were surveyed, papers and digital devices e.g., laptop, smart phone, etc. The result displayed that $39.3 \%$ of students frequently and $32.1 \%$ of students occasionally used paper. Meanwhile only $7.1 \%$ of students very frequently and $21.4 \%$ of students rarely used paper. In connection with digital devices, the data showed that respectively most of the students (46.4\% and $42.9 \%)$ very frequently and frequently used digital devices. And there were only $7.1 \%$ and $3.6 \%$ of students stated that they occasionally and rarely used digital devices respectively.

\section{Supporting writing activities}

In connection with supporting activities in writing as seen in Table 7 , the questionnaire indicated that majority $(28.6 \%)$ and $(32.1 \%)$ of the students made videos frequently and occasionally. Students making videos very frequently and rarely reached $10.7 \%$ and $21.4 \%$ respectively. Only $3.6 \%$ of students made video very rarely and never. In making pictures/posters, most of the students $(39.3 \%$ and $32.1 \%)$ made pictures/posters occasionally and frequently, while other students (17.9\% and $10.7 \%)$ made pictures/posters very frequently and rarely.

\section{Students' digital literacy in writing activities}

The last question in the questionnaire given to the students was digital literacy towards students' writing activities. This is to know the students' familiarity with audio visual editors/ applications such as Photoshops or Moviemaker. The data in Table 8 showed that the majority of the students $(42.9 \%$ and $25 \%$ ) were excellent and very good in digital literacy. Meanwhile there were only $17.9 \%$ and $14.3 \%$ of students were satisfactory and fair in utilizing the software in their writing activ- ities.

\section{Students'focus discussion findings}

Focus group discussion was conducted to gain more information which is not available in questionnaire regarding the students' literacy practices. From the questions about the rationality revealed that learning language using digital text was more eficient since it was reachable at any moment. "I like to use internet because it is very easy, and I can get it anytime," one of the students stated. Further, some students conveyed that they still used paper based text because they could make notes with ease.

I feel confortable when I am reading printed books. My eyes do not easily get tired. When I am listening to my lectures' explanantion in the class room, I can underline important words and give notes directly to my books. (FG, Student 2).

However, some of the students expressed that they joined journal reading club and extensive reading using both printed and online texts for their practice out of their classroom activities. In addition, they also utilized any sources from Internet and downloaded them. "I sometimes browsed some materials from website or Internet," one of the students said. 
Table 5. Types of writing activities

\begin{tabular}{lcccccc}
\hline Types of writing & Very frequently $\%$ & Frequently $\%$ & Occasionally $\%$ & Rarely $\%$ & Very rarely $\%$ & Never $\%$ \\
\hline Academic essays & 14.3 & 42.9 & 28.6 & 7.1 & 0 & 7.1 \\
Classnotes & 21.4 & 53.6 & 21.4 & 3.6 & 0 & 0 \\
Blogs & 10.7 & 21.4 & 32.1 & 17.9 & 7.1 & 10.7 \\
\hline
\end{tabular}

Table 6. Media used in writing

\begin{tabular}{lcccccc}
\hline Media of writing & Very frequently $\%$ & Frequently $\%$ & Occasionall y $\%$ & Rarely $\%$ & Very rarely $\%$ & Never $\%$ \\
\hline Papers & 7.1 & 39.3 & 32.1 & 21.4 & 0 & 0 \\
Digital devices & 46.4 & 42.9 & 7.1 & 3.6 & 0 & 0 \\
\hline
\end{tabular}

Table 7. Supporting writing activities

\begin{tabular}{lcccccc}
\hline Supporting writing activities & Very frequently \% & Frequently \% & Occasionally \% & Rarely \% & Very rarely \% & Never \% \\
\hline Making videos & 10.7 & 28.6 & 32.1 & 21.4 & 3.6 & 3.6 \\
Making pictures & 17.9 & 32.1 & 39.3 & 10.7 & 0 & 0 \\
\hline
\end{tabular}

Table 8. Students' digital literacy in writing activities

\begin{tabular}{lccccc}
\hline Students' competency & Excellent \% & Very good \% & Satisfactory \% & Fair \% & Poor \% \\
\hline Students' digital literacy & 42.9 & 25.0 & 17.9 & 14.3 & 0 \\
\hline
\end{tabular}

\section{Teachers' interviews and classroom observations findings}

Researcher conducted classrooms observations and interviews to the teachers to get the idea of their literacy strategies in reading and writing activities.

Based on the interviews conducted to the teachers, most of the teachers limited the concept of English language teaching into only the skills of English, Reading and Writing. Despite the fact that most of the teachers implemented multiple modes of teaching in their classroom, lack of understanding regarding the multiliteracies pedagogy and multimodal approach, digital divide, and target of courses delivered to the students became the issues of EFL teaching and learning. One teacher said, "I just focus on the subject skill that I teach based on the lesson plan."

\section{Focus of Teachers' literacy strategies in reading}

Use of texts (printed texts-based and digital texts-based reading practice)

The study deals with the use of texts covering printed and digital texts. Researcher asked the teachers about the mood of texts that they used during teaching and learning of Reading subject and their roles in integrating the texts into their interraction with the students. Despite the fact that students were provided by the teachers with the printed text-based reading books e.g., reading modules, the teachers responded that they suggested the students to search some other materials from the Internet or web pages as additional references.

Based on the observation, the two teachers were also familiar with the digital texts. Google Classroom was adopted as one of the digital media in teaching and learning. Google Classroom was intended to simplify the the distribution of materials and sharing information to the students. In Addition, they mostly utilized LCD projector and powerpoint to present the materials, however in some cases, they just deployed WhatsApp to share their materials. One teacher remarked, "When I have reading practices in the classroom, I just share them through WhatssApp, so I do not need to copy them."

\section{Multimodal literacy practices (visual, 2D multimedia production, and 3D multimedia production)}

Despite the use of digital text, in some other reading activities, the teachers implemented the use of posters to identify the structure of the texts. One of the teachers mentioned, "Students sometimes get bored if they just read the texts all the time. We need to use other media such as posters." The teacher further explained that in teaching reading, most of students found it difficult to understand the context of the text, therefore the videos to support their understanding became significant as one of the instructional tools. "The audio visual aids are very helpful for the students' understanding towards the texts," the teachers added. However, there was no reading activity which involved the $3 \mathrm{D}$ multimedia productions. 


\section{Focus of teachers' literacy strategies in writing}

Use of media (paper-based and digital-based writing media)

The researcher attempted to investigate the writing media used in teaching and learning writing. The teachers indicated that the media of writing were used depending on the situation and the materials of writing. During the observation, to manage the students' writing portofolio, the teachers suggested the students to provide a note book used in every single writing practice. One of the teachers stated, "By having note book, it will be easy for me to check the students' works and give them back to the students." Another teacher, however, asserted that the students had to type the writing assignments and email to the teacher.

As in reading classroom, teachers also asked the students to install Google Classroom application in their mobile phones to get the materials and information from the teachers. In addition to the use of digital texts, one teacher utilized Google Docs to correct and give feedbacks to the students' writing assignments. Nevertheless, some challenges were also faced in its implementation such as students' ability to operate Google Docs in submitting the assignments. "Google Docs application is very good media to teach writing, but we also have to teach the students how to use it," the teacher explained.

\section{Multimodal literacy practices (visual, 2D multimedia production, and $3 D$ multimedia production)}

During the observation, the researcher found that images were used in teaching writing. In the case of teaching descriptive paragraph, one of the teacher used the pictures of persons, things, and animals which were put on the classroom wall, and students in their groups observed as well as described the pictures. The teacher explicitly stated that involving writing activities with pictures increased the students enthusiasm in writing. In addition, some photographs were also displayed in PowerPoint with LCD projector to generate the idea of students in writing activities. After seeing the observation and interview, the data revealed that the most common writing activities involved 2D multimedia, and there was no writing activity involving the 3D multimedia production.

The summary of the emerging evidences above demonstrates the variety of reading and writing literacy strategies in the classrooms necessitating digital and multimodal lit- eracy instead of printed texts. These literacy practices were shifting from the traditional conception of paper based-text reading and writing literacy into digital and mulitmodal literacy. However, this changing nature of literacy practices still maintained and incorporated the conventional ones.

\section{DISCUSSIONS}

From the data obtained, the reseacher is generally interested in investigating literacy practices of the students and teachers in higher education level from digital and multimodal perspectives. In detail, the researcher is interested in discussing the investigation of students' literacy practices towards the use of printed, digital, and multimodal texts in reading and writing practices. Besides, the researcher is also interested in exploring the university teachers' literacy strategies of reading and writing in their EFL classrooms.

\section{Students' Literacy Practices towards the Use of Printed, Digital, and Multimodal texts}

\section{Students' reading practices}

Understanding the students' reading literacy practices, this research is concerned about the use of reading materials, modes of reading, supporting media for background knowledge buildings, and students' competency in using digital learning resources. Based on the data, the students frequently reading the materials from website such as online journal and newspaper were more than students who frequently read assigned books (modules) or other printed materials such as journals, book chapters, and proceedings. The students' propencity to use on screen texts indicated that most students were in possession of digital literacy utilized in their language learning, and digital texts provided in the Internet were more accessible. This is in line with the study of Prenski (as cited in Nabhan \& Irfan, 2017) that the characteristic of todays' students are different from those in the past time, and so called digital native, students who grow in the early $21^{\text {st }}$ century and know how to use the technology. This is to say that they are engaged with the technology. Despite the fact that reading digital texts mode was dominant, the students still maintained the use of printed texts. Mode of reading printed texts still remained bacause students still enjoyed reading printed texts provided by the teachers. Besides, students were also able to give reading notes or additional explanation delivered by teachers in the classrooms.

In students' reading practices, the majority of students frequently utilized the images and videos to support their comprehension towards the reading texts. Thus, it indicated that most of the students were audio visual learners. Using audio visual aids is essential in teaching language, which aligns with the findings in the study of Tan \& Libo (2009). Essentially, from the perspective of multimodal strategy, the use of visual aids to facilitate reading and writing instruction gives advantages for the students in making and representing the meaning in a creative way (Barton, 2015; Shaw, 2014). Finally, Since the literacy promotes students' independent learning (Gee, 2000; Hu \& McGrath, 2017), the study indicated positive result regarding the students' competency in 
utilizing digital learning resources. Majority of the students had no any hindrance towards digital access for their learning. From the study, it was found that one of the challenges in operating digital devices for learning was qualification disparities among the students (Center for Applied Linguistics, 2003).

Overall, inspite of the fact that students still retained the existance of printed texts for reading practices, digital and multimodal literacy were dominantly involved among the students.

\section{Students' writing practices}

In terms of students' writing practices, the study dealed with the types of writing, media use, supporting writing activities, and students' digital literacy. The data revealed that majority of students occasionally wrote academic essays. This might happen since the academic essays was only conducted during the course. However, most of the students frequently wrote classnotes from their lecturers. Furthermore, writing in blogs, unfortunately, was still unfamiliar to the majority of the students. The lack of familiarity of using blogs for practicing their writing due to fact that they did not have strong motivation and confidence to write in English. In fact, theoritically and empirically, it is essential to facilitate the students by employing media such as blogs to practice and express their idea into writing forms (Featro \& DiGregorio, 2016). In addition, referring to the data, the students' behavior was revealed towards the use of media for their writing activities, paper and digital divices. The existance of digital devices had lessened the use of paper. It was proven by the data that majority of the students very frequently used the digital devices, while some other students occasionally used papers. Thus, this traditional writing practices have changed into digital writing practices due to the advancement of technology.

Aside from using common media such as texts in their writing, other supporting writing activities involved making videos and pictures. The combination of texts with images or audio and visuals contribute to the practice of writing. This finding demonstrated how digital and multimodal literacy were merged with the texts. Referring to the concept of multimodal approach, the process of writing should cover the production of texts on paper that were transformed into digital and multimodal texts (Tan \& Libo, 2009). To gain those activities, students' skills should be developed, such as designing posters, slide shows, and editing videos with animation and sounds. Some software or application might be used such as Corel Draw, Movie Maker, or Adobe Photoshops. Thus, it became relevant to identify the students' digital literacy towards writing activities. From the survey, the data provided the evidence that most of students' were excellent and very good at digital literacy.

In summary, the digital writing practices had developed almost replacing the use of traditional methods such as writing on paper. However, the students' use of media for digital writing activities such as blogs or web pages still lacked.

\section{Teachers' Literacy Strategies in EFL Classrooms}

Multiliteracies pedagogy promotes the teaching and learning that focus on multimodality. Six different modes of meaning as suggested by Cazden, et al. (as cited in Greco, 2015) are crucial in this approach including linguistics, visual, audio, gestural, spacial, and multimodal as the medium to reinforce the students' multiliteracies. The findings of the study showed that the teaching and learning experiences within two literacy areas of reading and writing have expanded through the incorporation of print literacy with digital and multimodal literacy. This new strategy has abandoned the conventional approach that merely used text based learning. Notwithstanding the fact that the majority of the teachers implemented various literacy strategies in teaching reading and writing involving digital and multimodal literacy, the most common focus of literacy strategy was still on printed texts and digital texts, in which the teachers typically provided the students with printed modules and the use of Power- Point with LCD projector, while the multimodal approaches especially two and three dimension of spacial multimedia production were seldom performed. The insufficiency of use of spacial multimedia production was understood to be not necessary in terms of the target of courses.

In English language teaching and learning, the traditional conception regarding the goal of courses was still dominated in the institution of higher education. The mastery of English skill is just limited to merely the four skills of reading, writing, listening, and speaking. This misconception of English literacy education does not meet the challenge to face the today's sophisticated real world due to the rapid advancement of technology (Navehebrahim, (2011). This is to say, the literacy and the pedagogical strategies should develop and follow the expansion of globalization. As suggested by Tan \& Libo (2009) that designing the model in English language curriculum should infuse critical multimedia literacy lessons that range several focuses of initially engaging with the printed texts, reading with images, and producing images. This allows the students to engage with print based 2D multimodal texts. The next phase was to incorporate with multimodal texts (viewing videos), and finally to produce the $3 \mathrm{D}$ multimodal texts using software like Flash Makromedia as well as re-represent scenes. This sequence of lessons covers linguistic, visual, audio, spatial, and gestural representing multimodal approach.

Furthermore, since the target of courses in English Education Department is exclusively designed in the lesson plan, and there was no any direct relation to each skill, the practices of reading and writing were not connected each other. In addition, multimodal literacy should represent the interrelationship between different medium of texts, including traditional with digital and multimedia texts within the practice of reading and writing (Walsh, 2010). The redefinition of language and literacy indicates that the process of reading and writing is developing since the way of the technology has shifted the way of social communication including the classroom interaction. Such a way of interaction happens not only between the teachers and the students but also among 
the students. Furthermore, the perspective of multiliteracies suggests the production of $2 \mathrm{D}$ and $3 \mathrm{D}$ multimedia in reading and writing activities.

\section{CONCLUSIONS}

The findings of the study suggest that students as digital native have performed their use of technology and digital texts in their reading and writing activities. However, they still maintained the use of printed texts. The ability of students to demonstrate the multimodal texts was supported by the students'competency in using digital resources for their reading activities and their digital literacy in their writing activities. Therefore, with the students' potentiality in utilizing multimodal texts, teachers can reframe their pedagogy in English language education with multiliteracies.

Furthermore, despite the lack of familiarity of the teachers towards literacy theory and concept in the teaching of reading and writing, they have incorporated the print based media with the digital communication. This multiliteracy pedagogy and multimodality led to the shifting of nature in the EFL teaching and learning of reading and writing towards $21^{\text {st }}$ century literacy skills that enriched and contextualized the target of language to the real world experiences. Nevertheless, some difficulties faced by some teachers covering mainly in the goal of courses and students' qualification were still found in the implementation of the pedagogy and approach.

\section{ACKNOWLEDGEMENTS}

The authors would like thank to Ministry of Research, Technology, and Higher Education of the Republic of Indonesia for the supporting the grant for this research.

\section{REFERENCES}

Burke, A., \& Hardware, S. (2016). Honouring ESL students' lived experiences in school learning with multiliteracies pedagogy. Language, Culture and Curriculum, 143-157. Center for Applied Linguistics. (2003). Adult English lan- guage instruction in the $21^{\text {st }}$ century. Washington, DC: CAL.

Crowder, T. A., Choi, J., \& Yi, Y. (2013). Putting multilieracies into practices: Digital storytelling for multilingual adolescents in a summer program. TESL Canada Journal, 36-45.

Descombe, M. (2007). The good research guide for smallscale social research projects. Buckingham, UK: Open University Press.

Drajati, N. A., Tan, L., Haryati, S., Rochsantiningsih, D., \& Zainnuri, H. (2018). Investigating English language teachers in develping TPACK and multimodal literacy. Indonesian Journal of Applied Linguistics, 575-582.

Featro, S. M., \& DiGregorio, D. (2016). Bloggin as an instructional tool in the ESL classroom. TESL-EJ (Teaching English as a Second and Foreign Language Electronic Journal), 1-9.
Ganapathy, M., \& Seetharam, S. A. (2016). The effects of using multimodal approaches in meaning-making of $21^{\text {st }}$ century literacy texts among ESL students in a private school in Malaysia. Advances in Language and Literary Studies, 143-155.

Gee, J. (2000). New people in new worlds: Networks, the new capitalism and schools. In B. Cope, \& M. Kalantzis, Multiliteracies: literacy learning and the design of social futures (p. 26). London: Routledge.

Greco, C. D. (2015). Multiliteracies: bringing multimodality into schools. Education and Development Master's Theses, The College at Brockport: State University of New York.

Hu, Z., \& McGrath. (2017). Innovation in higher education in China: are teachers ready to integrate ICT in English language teaching. Technology, Pedagogy and Education, 41-59.

Krashen, S. (1990). How reading and writing make you smarter, or, how smart people read and write. In J. E. Alatis, Georgetown round table on language and linguistics (pp. 364-376). Washington, DC: Georgetown University Press.

Kress, G., Jewitt, C., Bourne, J., Franks, A., Hardcastle, J., Jones, K., et al. (2005). English in urban classrooms: A multimodal perspective on teaching and learning. London and New York: RoutledgeFalmer.

Nabhan, S., \& Rifai, I. (2017). What can be learned from classroom interactions and twenty-first century learning: Insight from teachers' perspective. The $3^{\text {rd }}$ English Teaching Conference (pp. 28-38). Surabaya: English Department, Faculty of Language and Art, Universitas Negeri Surabaya.

Navehebrahim, M. (2011). Multiliteracies approach to empower learning and teaching engagement. International Conference on Education and Educational Psychology (pp. 863 -868). Malaysia: Procedia - Social and Behavioral Sciences.

Paxton, M., \& Frith, V. (2014). Implication of academic literacies research for knowledge making and curriculum design. Higher Education, 171-183.

Scribner, S., \& Cole, M. (1981). The psychology of literacy. Cambridge, MA: Harvard University Press.

Tan, L., \& Libo, G. (2009, Dec). From print to critical multimedia literacy: one teacher's foray into new literacies practices. Journal of Adolescent \& Adult Literacy 53 (4), 315-324.

The New London Group. (2011). A pedagogy of multiliteracies: Designing social futures. Harvard Educational Review, 60-93.

Walsh, M. (2010). Multimodal literacy: What dose it mean fot classroom practice? Australian Journal of Language and Literacy 